Int. J. Odontostomat.,

15(1):36-42, 2021.

\title{
New Rules for Teaching in Dental Schools in the COVID-19 Era
}

\author{
Nuevas Normas para la Enseñanza en las \\ Facultades de Odontología en la Era COVID-19
}

\begin{abstract}
Ana Leticia Lenguas-Silva1; María Victoria Mateos-Moreno1; Germán García-Vicent'; Marta Lamas-Oliveira"; José Francisco Martín-Morales ${ }^{1}$; Javier Valdepeñas-Morales ${ }^{2}$ \& María Rosario Garcillán-Izquierdo ${ }^{3}$
\end{abstract}

LENGUAS-SILVA, A. L.; MATEOS- MORENO, M. V.; GARCÍA-VICENT, G.; LAMAS-OLIVEIRA, M.; MARTÍN-MORALES, J. F.; VALDEPEÑAS-MORALES, J. \& GARCILLÁN-IZQUIERDO, M. R. New rules for teaching in dental schools in the COVID 19 era. Int. J. Odontostomat., 15(1):36-42, 2021.

ABSTRACT: The crisis caused by COVID-19 has led to the development of strategies for adapting the undergraduate and postgraduate teaching of dentistry to the new situation, as well as guaranteeing the safety of all staff, students, patients and persons accompanying them. We reviewed a total of 36 documents, including articles and guidelines or recommendations issued by dental schools, scientific societies and other institutions, in order to take stock of the current evidence available about the impact of the COVID-19 pandemic on dental schools. Additional training is required in the management of infectious diseases and the prevention of their transmission. Dental schools must be prepared and implement the necessary measures according to the level of infection risk during face-to-face activities, especially in clinics, while guaranteeing quality teaching and allowing research to be carried out. Adapting teaching to new technologies is essential for the development of non-classroom training, as is conducting questionnaires that collect information on crisis management and assessing the stress level of students, faculty and other staff. The incorporation of new technologies in both training and assessment reduces the chances of contagion and enhances student autonomy. Distance learning competencies must be clear to students and be included in the description of the academic programme. We must not forget that the primary objective of teaching is for students to acquire the necessary skills for their profession. More than ever, the international cooperation of universities in the elaboration of protocols is essential. These protocols must ensure the health of everyone in this pandemic and in possible future scenarios. We must transform this crisis into an opportunity that will revolutionize dental education.

KEY WORDS: dental schools, dental education, distance learning, prevention, COVID-19, SARS-CoV-2.

\section{INTRODUCTION}

According to the WHO, COVID-19 is the infectious disease caused by the SARS-CoV-2 coronavirus that started in Wuhan (China) in December 2019. Currently, COVID-19 is a pandemic that affects most countries around the world.

Today it is known that the SARS-CoV-2 virus is mainly transmitted by the respiratory route (respiratory drops and aerosols) and by direct contact with contaminated surfaces and subsequent contact with nasal, oral or ocular mucosa (Whitworth, 2020).
Though the evidence on the possible transmission of SARS-CoV-2 through aerosols is not yet completely clear (Chen, 2020; Zhou et al., 2020) there is an increasing sense of the need to address this potential way of propagation, (Morawska \& Milton, 2020) which is particularly relevant in the field of dentistry.

Recent observations suggest that asymptomatic and incubation patients (pre-symptomatic) also have the ability to transmit SARS-CoV-2 (Chan et al.,2020;

\footnotetext{
${ }^{1}$ Assistant professor of the Department of Dental Clinical Specialties. School of Dentistry, Madrid Complutense University. Madrid. Spain.

2 Honorary Collaborating Professor of Department of Dental Clinical Specialties. School of Dentistry, Madrid Complutense University. Madrid., Spain.

${ }^{3}$ Vice-Dean and Tenured Assistant Professor of the Department of Dental Clinical Specialties. School of Dentistry, Madrid Complutense University, Madrid, Spain.
}

Received: 2020-09-11 Accepted: 2020-10-18 
Izzetti et al., 2020; Rothe et al., 2020). The incubation period is usually from 2-12 days, it can vary from 0 to 24 days, therefore, transmission can occur before any symptoms are apparent (Chan et al.; Izzetti et al., 2020).

The risk of contamination is very high on upper respiratory examinations. Greater viral loads were detected after the onset of COVID-19 symptoms, with a higher viral load in the nose than in the throat (Kowalski et al., 2020; Wang et al., 2020).

Due to the unique characteristics of dental procedures, where large amounts of drops and sprays can be generated, standard protective measures in daily clinical work may not be effective enough to prevent the spread of COVID-19, especially when patients are in the incubation period, do not know they are infected, or choose to hide their infection (Rothe et al.).

\section{Implications of the new situation}

The COVID-19 pandemic constitutes a very complicated health crisis, especially in a globalized world that enables very fast international transmission, and has driven many radical societal changes, also and perhaps especially in the teaching field.

Thanks to a strong healthcare system and the commitment, resilience and qualification of health professionals, thousands of lives have been saved and an effort to help every patient in need has been made. The healthcare providers have adapted to the changing environment with an attitude of motivation and dedication.

The other important measure that was taken was the confinement of the population to avoid viral transmission. However, a fundamental epidemiological truth was sometimes forgotten: in any infectious disease there are infected but asymptomatic people who must be detected, isolated and monitored.

We have the important task of protecting the health of students, faculty, patients and administrative staff in this moment of change, at the same time ensuring continuity in the quality and training of students.

Dental schools have their own idiosyncrasy: different profiles of workers include administrative, management and teaching staff and researchers.
Besides of the personnel there are of course also the students, along with patients with greater or lesser risk according to their health condition and the type of activity undertaken.

Students feel insecure having to adjust to new training methods and are fearful and uncertain about their own health and also about their training (Quinn et al., 2020). There has been very little research on the impact of the pandemic caused by the new coronavirus on dental education (Prati et al., 2020).

Said reasons has motivate this work: the research of the evidence on the implications in dental education to develop strategies for adapting the undergraduate and postgraduate teaching of dentistry to the new situation and protocols that guarantee the safety of all.

These protocols must ensure the health of everyone in this pandemic and in possible future scenarios.

\section{MATERIAL AND METHOD}

The bibliographic search has been carried out in MEDLINE (via Pubmed database) using the following MeSH (Medical Subjects Headings) terms: (dental schools OR dental education OR distance learning OR prevention) AND (COVID-19 OR Sars-CoV-2). In addition, web pages of international official organizations, national guides, scientific societies, dental schools and other institutions of dental education worldwide, were revised using the following search terms: PubMed (Medline) and on the websites of international official organizations, national guides, scientific societies, dental schools and other institutions of dental education worldwide using the following search terms: dental schools, dental education, distance learning, prevention, COVID-19, SARS-CoV2. We found 36 articles, most of them observational and based on the experts review of the evidence currently available with very few experimental ones.

\section{RESULTS- DISCUSSION}

Nowadays, information and communication technologies (ICTs) allow a variety of communication processes between academics and students (Chiyong 
et al., 2016). We have to accelerate technological change, incorporating new technologies and new ways of working, making the most of human capital and being conscious that unified action is an essential value in the control of the disease.

Being in an environment that changes every minute, it is imperative that dental schools make appropriate and timely modifications to their teaching and learning methods to ensure continuity of education, and implement interim policies and protocols to protect the staff, students, faculty and patients (lyer et al., 2020)

\section{Necessary changes in teaching and learning}

We are committed to the best possible teaching, considering the safety obligations, the inescapable need for clinical care, the number of teachers and students and the teacher/student ratios in the different activities, the number of administrative personnel and the structure of the facilities.

\section{a) General measures:}

It is essential to prioritize health prevention criteria.

The risk assessment for dental school staff and students is necessary, which is why the Occupational Risk Prevention Service (ORPS) is of great importance.

The ORPS must define the risk of the dental school staff according to the interventions they take part in: administrative staff are low risk, while clinic assistants, teachers and students are high risk.

The ORPS will also be responsible for examining all personnel at the beginning of their shift in order to detect fever and / or symptoms suggestive of COVID-19.

In addition, it will be responsible for the development of adequate protocols for preventing SARS-CoV-2 infection and for the education and training of staff and students focused on the control and prevention of the disease, including the placement of information posters specifically targeted at faculty, students and patients in different areas of the premises (Coulthard, 2020; Ministerio de Sanidad, 2020; Peditto et al., 2020). Students must receive additional training in the prevention of the transmission of infectious diseases (Ghai, 2020) for which the use of standard questionnaires ("checklists") can be very helpful (Consejo de Dentistas, 2020).

All these aspects have been included in the "Guide of preventive recommendations for resuming activity in the dental school of the Complutense University of Madrid in relation to the potential exposure to SARS-CoV-2" designed in the Vicedeanship of Clinics of the Faculty of UCM Dentistry (Facultad de Odontología, Universidad Complutense de Madrid, 2020).

In the UCM dental school, different activities are carried out:

- Teaching activity, which aims to provide students with the necessary knowledge to develop their clinical skills according to the European Education Area (Gao et al., 2015).

- Research activity, necessary for the development of the clinic and its updating.

Healthcare activity, which commits us to the achievement and maintenance of patient health, while developing student training.

\section{b) Regulation of access and prevention of contagion in the Faculty:}

In order to access the UCM Dental School, every person (both patients and students, professors, administrative staff, etc.) must carry out all the protection measures designed for this purpose (Facultad de Odontología, Universidad Complutense de Madrid):

- Staggered access to the Dental School.

- Temperature control. With more than $37,5^{\circ} \mathrm{C}$ access is not allowed. (Universitá degli Studi dell'Insubria, 2020).

- Mandatory use of surgical mask throughout the premises. According to order SND / 422/2020 (May $31,2020)$, the use of the mask by the general population is justified by the high transmissibility of the virus and by the ability of the masks to block the transmission of infected drops.

- Desinfect hands with $70 \%$ hydroalcoholic gel placed at the entrance. 
LENGUAS-SILVA, A. L.; MATEOS- MORENO, M. V.; GARCÍA-VICENT, G.; LAMAS-OLIVEIRA, M.; MARTÍN-MORALES, J. F.; VALDEPEÑAS-MORALES, J. \& GARCILLÁNIZQUIERDO, M. R. New rules for teaching in dental schools in the COVID 19 era. Int. J. Odontostomat., 15(1):36-42, 2021.

- Remember frequent hand washing as a preventive measure.

- Infographics on how to properly wash hands (Universidad del Valle, 2020) will be placed in the toilets.

- It is recommended that the activity of libraries be reduced exclusively to online loans while the current scenario of risk of contagion by COVID-19 persists. The replacement of books, magazines, etc., by electronic resources will be considered.

\section{c) Adaptation plan for theoretical teaching:}

At the current stage of the evolution of the pandemic, theoretical teaching will not be done in person. Attendance to the dental school will be limited to those activities that cannot be carried out remotely. So:

- It should be borne in mind that theoretical teaching is easier to carry out on-line than practical teaching, since it does not require manual skills. Despite this, on-line teaching requires a different preparation than face-to-face and also a different duration.

- It is possible to hold on-line debates with the students on different topics of the syllabus (Moazami et al., 2014; Bridges et al., 2014; Ramlogan et al., 2014; Evaristo et al., 2016; Zheng et al., 2017; SuasnabasPacheco et al., 2019).

- Platforms such as Zoom, Google Meet, etc. will be used (Sandhu \& de Wolf, 2020).

- It will advance towards the virtualization of the subjects, developing along this lines the teaching programming and the evaluation methods.

For adaptation to theoretical classroom teaching in the future, the following standards will have to be met:

a. Provision of hydroalcoholic gels placed at the entrances to the classrooms and reading rooms.

b. Every effort will be made to use the biggest classrooms available to facilitate physical distancing.

d) Plan of progressive adaptation to pre-clinical classroom teaching:

- Groups of smaller students will be organized to carry out preclinical activities in shifts and with the same protection measures previously mentioned. More teachers are needed when distributing students in different shifts.

- The $1.5 \mathrm{~m}$ distance between students and the mandatory use of a mask will be enforced.

- In preclinical teaching, problem-based learning (PBL) guarantees the acquisition of important concepts (Suasnabas-Pacheco et al.; Zheng et al., 2017).

For the acquisition of manual skills and abilities, short demonstration videos of the different dental techniques can be used (Suasnabas-Pacheco et al.; Zheng et al.) Mobile applications and videos demonstrating preclinical and clinical learning methods could be an effective solution and help to reinforce student autonomy (listening to and revisiting classes as many times as possible) (Chiyong et al.).

- Videos in which questions can be inserted (ED puzzle), can also be used for preclinical teaching, and the student can answer while viewing the video (Ramlogan et al.).

- The use of simulators allows us to train students individually in manual skills, knowing the textures of the different layers of the teeth. Virtual reality simulators with tactile feedback functionalities make it possible to "feel and touch" virtual dental tissue. There is scientific evidence that virtual technology improves the acquisition of skills in operative dentistry modules (Buchanan, 2001; Barabari \& Moharamzadeh, 2020). It improves eye-hand coordination, fine motor skills and reflexes, being very adequate in the early stages of skill acquisition (AlSaud et al., 2017).

- It will be interesting to enhance virtual reality in preclinical activity (Barabari, \& Moharamzadeh., 2020).

\section{e) Plan for progressive adaptation to clinical classroom teaching:}

It is important pointing out that:

- No virtual session replaces the close experience with the patient for the development of skills (Zheng et al., 2017; Suasnabas et al., 2019; Alzahrani et al., 2020; lyer et al., 2020). Various activities can be incorporated that complement, but never replace, clinical activities. Seminars can be conducted 
LENGUAS-SILVA, A. L.; MATEOS- MORENO, M. V.; GARCÍA-VICENT, G.; LAMAS-OLIVEIRA, M.; MARTÍN-MORALES, J. F.; VALDEPEÑAS-MORALES, J. \& GARCILLÁNIZQUIERDO, M. R. New rules for teaching in dental schools in the COVID 19 era. Int. J. Odontostomat., 15(1):36-42, 2021.

analyzing clinical cases, diagnosis and possible treatments according to PBL Problem Based Learning.

- Clinical teaching should be recovered when the faceto-face situation allows it.

- It will be necessary to establish a rotation regime for face-to-face activities.

In order to access the clinic, all the regulations of the Guide of preventive recommendations for resuming activity in the dental school of the Complutense University of Madrid in relation to the potential exposure to SARS-CoV-2" designed in the Vice-deanship of Clinics of the Faculty of UCM Dentistry will have to be adhered to (Facultad de Odontología, Universidad Complutense de Madrid).

A series of specific measures are well established and the mobility circuits are determined depending of the elements (semi-critical or critical areas) in dental school.

Patient management, organization of agendas, telephone triage and clinical work must be perfectly described in clear protocols that include PPE recommendations according to the risk of the activity; assigning well-defined responsibilities will decrease anxiety and help towards the physical and psychological well-being of students, faculty and other staff.

It is interesting to promote Minimally Interventional Dentistry, based on the current fundamental pillar of caries prevention and treatment: "preserve dental structure and restore only when indicated". An important point would be the incorporation of materials that simplify dental techniques in a situation when the time in the dental office must be optimized and dental treatments generating aerosols must be minimized - for example, with the use of agents such as silver amino fluoride, hydrophilic sealants, or glass ionomers.

\section{f) Evaluation}

- Online exams are not adequate in healthcare degrees, since they only assess theoretical skills (Bridges et al.; Brummini et al., 2014; Moamazi et al., 2014; Ramlogan et al.; Zheng et al., 2017).

- We must make an effort to perform a continuous, progressive evaluation in order to know how the students are acquiring their competences.

- The competences that the student has to demonstrate as well as the evaluation criteria should be defined so that the students know what is going to be demanded of them and all are evaluated in the same way (Alsina et al., 2013; Agencia Nacional de Evaluación de la Calidad y Acreditación, 2020).

The systems may vary: questionnaires, short questions, essays, clinical cases or an oral examination by at least two teachers.

\section{g) Research}

- The impact on research has meant a focus on conducting online surveys and review articles, while projects that included clinical trials or required tests in laboratories which have remained closed had to be suspended.

- All research on COVID-19 has been prioritized: cross infection control, PPE, innovation in remote consultation, alternative methods in dental education and training.

\section{h) Possible future scenarios and action plans}

Dental schools should focus on reevaluating and prioritizing their policies and protocols and include a detailed contingency plan in case of future pandemics. This experience should also prompt dental schools to reevaluate their competency-based education, permanently incorporate variations of remote learning into their curricula, invest in haptic technology to improve psychomotor skills, and also in teacher training for teach through technology. Extramural rotations and interprofessional education should be strengthened in curricula to allow dental students the ability to impact the community and help during this kind of crisis.

Technology in teaching and learning should be used when appropriate after adequate teacher training in remote teaching. The success of e-learning depends on the teachers' interactive attitudes and teaching styles, as well as the students' experience and attitudes towards technology. Although there may be challenges in learning in this field, educational institutions should not wait for a new emergency to include online courses or e-learning elements in the courses and measure their effectiveness from a pedagogical, organizational, teaching and Learning. 


\section{CONCLUSIONS}

- In the university environment in which we operate, it is essential to develop the appropriate strategies that guarantee the safety of all the personnel involved, as well as the students and patients who come to the center.

- We must not forget that the primary objective of teaching is for students to acquire the necessary skills for their profession, even while they receive information and training on prevention and public health measures for COVID-19.

- In this context, health promotion and preventive dentistry and public health become even more important. Students must receive additional training in preventing the transmission of infectious diseases.

- The incorporation of new technologies in both training and assessment reduces the chances of contagion and enhances student autonomy. It is an opportunity to revolutionize dental education. Hybrid teaching is here to stay.

- Distance learning competencies must be clear to students and be included in the description of the academic programme.

- Financing of projects for the development of new teaching methods will guarantee sufficient computer support through virtual technologies to facilitate dental training, and it should be promoted.

- In this new context, stress management and psychological support for all staff, students and the center, both directly and using computer technologies (web or emergency telephone line in case of difficulty) are necessary to cope with the new day-to-day situations.

- Today more than ever, the national and international collaboration among universities is necessary to redefine dental studies and adapt them to the new reality. We must be prepared for a possible second wave of the virus or other future epidemics.

LENGUAS-SILVA, A. L.; MATEOS- MORENO, M. V.; GARCÍA-VICENT, G.; LAMAS-OLIVEIRA, M.; MARTÍNMORALES, J. F.; VALDEPEÑAS-MORALES, J. \& GARCILLÁN-IZQUIERDO, M. R. Nuevas normas para la enseñanza de la Odontología en la era COVID-19. Int. J. Odontostomat., 15(1):36-42, 2021.
RESUMEN: La crisis originada por la COVID-19 ha obligado a desarrollar estrategias para adaptar la enseñanza pre y postgrado en odontología a la nueva situación, así como para garantizar la seguridad de todo el personal de la facultad, estudiantes, pacientes y acompañantes. Revisamos un total de 36 documentos, incluyendo artículos y guías o recomendaciones facilitadas por facultades de odontología, sociedades científicas y otras instituciones, con el fin de obtener la evidencia científica disponible sobre el impacto de la pandemia de la COVID-19 en las facultades de odontología. Las facultades de odontología deben estar preparadas e implementar las medidas necesarias según el nivel de riesgo de infección de SARS-CoV-2 durante las actividades presenciales, especialmente en clínica, además de garantizar una enseñanza de calidad y permitir el desarrollo de investigación. Es fundamental la adaptación de la docencia a las nuevas tecnologías para el desarrollo de formación no presencial, así como la realización de cuestionarios que recaben información sobre la gestión de la crisis y analicen el estrés de estudiantes, profesores y personal. La incorporación de las nuevas tecnologías tanto en la formación como en la evaluación reduce las posibilidades de contagio y potencia la autonomía del alumno. Las competencias de la educación a distancia deben quedar claras para los estudiantes, e incluirse en la descripción del curso académico siendo objetivo primordial de la docencia la adquisición de las mismas. La cooperación internacional de universidades es esencial en la elaboración de protocolos que garanticen la salud de todos en esta pandemia y en posibles futuros escenarios. Esta crisis supone una oportunidad para revolucionar la educación en odontología.

PALABRAS CLAVE: facultades de odontología, educación en odontología, aprendizaje a distancia, prevención, COVID-19, SARS-CoV-2.

\section{REFERENCES}

Al-Saud, L. M.; Mushtaq, F.; Allsop, M. J.; Culmer, P. C.; Mirghani, I.; Yates, E. Keeling, A.; Mon- Williams, M. A. \& Manogue, M. Feedback and motor skill acquisition using a haptic dental simulator. Eur. J. Dent. Educ., 21(4):240-7, 2017.

Alsina, M. J.; Argila, I. A.; Aróztegui, T. M.; Arroyo, C. F. J.; Badia, M. M.; Carreras, M. A.; Colomer, B. M.; Gracenea, Z. M.; Halbaut, B. L.; Juárez, V. P.; et al. Rúbricas para la Evaluación de Competencias. Barcelona, Ediciones Octaedro, 2013. Available at: https://pt.slideshare.net/MarlyRc/rúbricas-para-la-evaluación-decompetencias

Alzahrani, S. B.; Alrusayes, A. A. \& Aldossary, M. S. Impact of COVID19 pandemic on dental education, research, and students. Int. J. Health Sci. Res., 10(6):207-12, 2020.

Agencia Nacional de Evaluación de la Calidad y Acreditación (ANECA). Guía de Apoyo para la Redacción, Puesta en Práctica y Evaluación de los Resultados del Aprendizaje. Madrid, Agencia Nacional de Evaluación de la Calidad y Acreditación, 2013. Available from: http:/ /www.aneca.es/Documentos-y-publicaciones/Otras-guias-y-documentos-de-evaluacion/Guia-de-apoyo-para-la-redaccion-puesta-enpractica-y-evaluacion-de-los-RESULTADOS-DEL-APRENDIZAJE Barabari, P. \& Moharamzadeh, K. Novel Coronavirus (COVID-19) 
and dentistry-A comprehensive review of literature. Dent. J. (Basel), 8(2):53, 2020.

Bridges, S.; Chang, J. W. W.; Chu, C. H. \& Gardner, K. Blended learning in situated contexts: 3-year evaluation of an online peer review project. Eur. J. Dent. Educ., 18(3):170-9, 2014.

Buchanan, J. A. Use of simulation technology in dental education. J. Dent. Educ., 65(11):1225-31, 2001.

Chan, J. F. W.; Yuan, S.; Kok, K. H.; To, K. K. W.; Chu, H.; Yang, J.; Xing, F.; Liu, J.; Yip, C. C. Y. Y.; Poon, R. W. S.; et al. A familial cluster of pneumonia associated with the 2019 novel coronavirus indicating person-to-person transmission: a study of a family cluster. Lancet, 395(10223):514-23, 2020.

Chen, J. Pathogenicity and transmissibility of 2019-nCoV-A quick overview and comparison with other emerging viruses. Microb. Infect., 22(2):69-71, 2020.

Consejo de Dentistas. Plan Estratégico de Acción para el Periodo Posterior a la Crisis Creada por el COVID-19. Madrid, Consejo de Dentistas, Organización Colegial de Dentistas de España, 2020.

Coulthard, P. Dentistry and coronavirus (COVID-19) - moral decisionmaking. Br. Dent. J., 228:503-5, 2020.

Durán-Ojeda, G. Educación en odontología para las asignaturas de simulación preclínica en tiempos de Pandemia por COVID-19. Int. J. Dent. Sci., 22(2):10-3, 2020.

Chiyong, T. E.; Villacampa, S. C.; Fernández, L. O.;Moncada, D. S.; Castro, M. J. \& Ayala de la Vega, G. Conocimiento, aplicación y apreciación de la Tecnología de la Información y Comunicación (TIC) 2.0 por estudiantes y docentes de la Facultad de Odontología de la Universidad Nacional Mayor de San Marcos: Pregrado y posgrado. Odontol. Sanmarquina, 19(1):22-7, 2016.

Facultad de Odontología, Universidad Complutense de Madrid. Protocolo de Medidas Organizativas y Específicas: Guía de Recomendaciones Preventivas para la Reincorporación en la Facultad de Odontología de la Universidad Complutense de Madrid en Relación a la Potencial Exposición al SARS-CoV-2 (v20200601). Madrid, Facultad de Odontología, Universidad Complutense de Madrid, 2020. Available from: https:// odontologia.ucm.es/file/guiareincorporacion

Gao, X.; Wong, L. M.; Chow, D. Y. S.; Law, X. J. \& Ching, L. Y. L. Learning clinical procedures through Internet visual resources: a qualitative study amongst undergraduate students. Eur. J. Dent. Educ., 19(1):38-43, 2015.

Ghai, S. Are dental schools adequately preparing dental students to face outbreaks of infectious diseases such as COVID-19? J. Dent. Educ., 84(6):631-3, 2020.

Iyer, P.; Aziz, K. \& Ojcius, D. M. Impact of COVID-19 on dental education in the United States. J. Dent. Educ., 84(6):718-22, 2020.

Izzetti, R.; Nisi, M.; Gabriele, M. \& Graziani, F. COVID-19 transmission in dental practice: brief review of preventive measures in Italy. J. Dent. Res., 99(9):1030-8, 2020.

Kowalski, L. P.; Sanabria, A.; Ridge, J. A.; Ng, W. T.; de Bree, R.; Rinaldo, A.; Takes, R. P.; Mäkitie, A. A.; Carvalho, A. L.; Bradford, C. R.; et al. COVID-19 pandemic: Effects and evidence-based recommendations for otolaryngology and head and neck surgery practice. Head Neck, 42(6):1259-67, 2020.

Ministerio de Sanidad. Procedimiento de Actuación para los Servicios de Prevención de Riesgos Laborales frente a la Exposición al SARS-CoV-2. 7 de octubre de 2020. Madrid, Ministerio de Sanidad, Gobierno de España, 2020. Available from: https:// www.mscbs.gob.es/profesionales/saludPublica/ccayes/ a I e r t a s A c t u a I/ n Cov/documentos/ Proteccion_Trabajadores_SARS-CoV-2.pdf

Moazami, F.; Bahrampour, E.; Azar, M. R.; Jahedi, F. \& Moattari, M. Comparing two methods of education (virtual versus traditional) on learning of Iranian dental students: a post-test only design study. BMC Med. Educ., 14:45, 2014.
Morawska, L. \& Milton, D. K. It is time to address airborne transmission of COVID-19. Clin. Infect. Dis., ciaa939, 2020.

Peditto, M.; Scapellato, S.; Marcianò, A.; Costa, P. \& Oteri, G. Dentistry during the COVID-19 Epidemic: An Italian Workflow for the Management of Dental Practice. Int. J. Environ. Res. Public Health, 17(9):3325, 2020.

Prati, C.; Pelliccioni, G. A.; Sambri, V.; Chersoni, S. \& Gandolfi, M. G. COVID-19: its impact on dental schools in Italy, clinical problems in endodontic therapy and general considerations. Int. Endod. J., 53(5):723-5, 2020.

Quinn, B.; Field, J.; Gorter, R.; Akota, I.; Manzanares, M. C.; Paganelli, C.; Davies, J.; Dixon, J.; Gabor, G.; Mendes, R. A.; et al. COVID-19: the immediate response of European Academic Dental Institutions and future implications for dental education. Eur. J. Dent. Educ., 2020. DOI: https://www.doi.org/10.1111/ eje.12542

Ramlogan, S.; Raman, V. \& Sweet, J. A comparison of two forms of teaching instruction: video vs. live lecture for education in clinical periodontology. Eur. J. Dent. Educ., 18(1):31-8, 2014.

Rothe, C.; Schunk, M.; Sothmann, P.; Bretzel, G.; Froeschl, G.; Wallrauch, C.; Zimmer, T.; Thiel, V.; Janke, C.; Guggemos, W.; et al. Transmission of 2019-nCoV infection from an asymptomatic contact in Germany. N. Engl. J. Med., 382(10):970-1, 2020.

Sandhu, P. \& de Wolf, M. The impact of COVID-19 on the undergraduate medical curriculum. Med. Educ. Online, 25(1):1764740, 2020.

Suasnabas-Pacheco, L. S.; Campos-Mancero, O. V.; Rivera-Guerrero, C. P.; Zumba-Macay, R. \& Escudero-Doltz, W. Una mirada de las tecnologías de información y la comunicación en odontología. Dominio Cienc., 5(2):497-522, 2019.

Universidad del Valle. Protocolo de Actuación COVID-19. Cali, Universidad del Valle, 2020. Available from: https://univalle.edu.ni/ protocolo-de-actuacion-covid-19-2/

Wang, W.; Xu, Y.; Gao, R.; Lu, R.; Han, K.; Wu, G. \& Tan, W. Detection of SARS-CoV-2 in different types of clinical specimens. JAMA, 323(18):1843-4, 2020.

Whitworth, J. COVID-19: a fast evolving pandemic. Trans. R. Soc. Trop. Med. Hyg., 114(4):241-8, 2020.

Zheng, M.; Bender, D. \& Nadershahi, N. Faculty professional development in emergent pedagogies for instructional innovation in dental education. Eur. J. Dent. Educ., 21(2):67-78, 2017.

Zhou, P.; Yang, X. L.; Wang, X. G.; Hu, B.; Zhang, L.; Zhang, W.; Si, H. R.; Zhu, Y.; Li, B.; Huang, C. L.; et al. A pneumonia outbreak associated with a new coronavirus of probable bat origin. Nature, 579:270-3, 2020.

Corresponding author:

Ana Leticia Lenguas Silva

Departamento de Especialidades Clínicas Odontológicas

Facultad de Odontología

Universidad Complutense de Madrid

Plaza Ramón y Cajal, s/n

Ciudad Universitaria

28040-Madrid

SPAIN

E-mail: alenguas@pdi.ucm.es 